\title{
Assessment of Patulin Content in Apple Puree and Apple and Fruit Puree by High Performance Liquid Chromatography
}

\author{
Monica Catana ${ }^{1}$, Luminita Catana ${ }^{1}$, Enuta Iorga ${ }^{1}$, Mioara Negoita ${ }^{1}$, Valentin Ionescu ${ }^{1}$, Nastasia Belc ${ }^{1}$, Dragos \\ Efstatiade $^{2}$ and Hassan Y. Aboul-Enein ${ }^{3}$ \\ 1. National R \& D Institute for Food Bioresources-IBA, 6 Dinu Vanita Street, Bucharest 2 021102, Romania \\ 2. Pro Analysis Systems, 29 Sfanta Vineri Street, Bucharest 030203, Romania \\ 3. Department of Pharmaceutical and Medicinal Chemistry, The Pharmaceutical and Drug Industries Research Division, National \\ Research Centre, Dokki, Giza 12622, Egypt
}

\begin{abstract}
An analytical method was developed and validated for determination of patulin in apple puree by HPLC. Extraction and clean-up of patulin from clear extract are achieved on AFFINIMIP ${ }^{\circledR}$ SPEPATULIN cartridges. Patulin is then separated on a Hypersil GOLD column $150 \mathrm{~mm} \times 4 \mathrm{~mm}, 5 \mu$ mand detected at $276 \mathrm{~nm}$. The recovery in the range of $5 \mu \mathrm{g} / \mathrm{kg}-80 \mu \mathrm{g} / \mathrm{kg}$ was $81.47 \%$. The limit of detection (LOD) was $1.36 \mu \mathrm{g} / \mathrm{kg}$, and the limit of quantification (LOQ) was $4.55 \mu \mathrm{g} / \mathrm{kg}$. The patulin content of the commercial samples of apple puree and samples of apple and fruit puree forinfants and young children as well as the samples of apple puree prepared from two apple varieties intended for processing (Jonathan, Florina) and obtained from conventional and uncertified organic cultures has been evaluated in this paper. The $44.83 \%$ patulin concentration of the analyzed samples were under the maximum level of the European Commission Regulation (EC) $1881 / 2006$, in $46.55 \%$ of the analyzed samples patulin was not detected and in $8.62 \%$ of samples patulin concentration was lower than LOQ (European Comission, 2006a) Patulin was not detected in samples of apple puree intended for infants and young children consumption.
\end{abstract}

Key words: Patulin, HPLC-DAD, apple puree, method performance parameters.

\section{Introduction}

Mycotoxins are metabolites of fungi, which are able to causeacute or chronical toxic effects (cancerigenes, mutagenes, teratogenes) on animals and humans. Patulin is a mycotoxin produced by a range of fungal species, generally Penicillium, Aspergillus and Byssochlamys, of which Penicillium expansum is probably the most prevalent species. Patulin was discovered as contaminant in fruits and vegetables, but moldy apple and their processed products are the main contamination source ofthis mycotoxin. Initially, patulin was considered as having therapeutic effect, as a result of antibiotic

Corresponding author: Hassan Y. Aboul-Enein, Ph.D., main research field: pharmaceutical, biomedical and environmental analysis. properties. But in 1960s it was reclassified as mycotoxin because of its toxicity [1]. The investigations undertaken have shown that patulin has mutagenic, neurotoxic, immunotoxic, genotoxic effectsonrodents and different effects on gastrointestinal tract,such as distensia, ulceration and bleeding [2]. International Agency for Research on Cancer (IARC-Geneva, Switzerland) has classified patulinas group 3 (Not classifiable as to its carcinogenicity to humans) concerning its potential as a human carcinogen [3].

The Joint Food and Agriculture Organization/World Health Organization Expert Committee on Food Additives (JEFCA) proposeda provisional maximum tolerable daily intake (PMDTI) of $0.4 \mu \mathrm{g} / \mathrm{kg}$ body weight/day, based on reproductive and carcinogenicity studies and its toxicity [4]. 
Patulin appearsmainly in moldy fruits. Although the presence of mold does not necessarily imply the presence of patulin in fruit, it indicates the possibility. In some circumstances, the inside development of molds may be due to insects or other invasions of healthy tissues, leading to the appearance of patulin in fruit, which externally appears to be unaffected. However, patulin may occur in hit fruits after the storage under controlled atmosphere and exposure to the environmental conditions, with or without fruit pulp alteration. Washing fruit or removing of moldy tissue immediately before pressing will not remove patulin in the fruit, because it diffuses in the apparently healthy tissue [5].

According to IUPAC, patulin is chemically known as 4-hydroxy-4H-furo[3,2-c]pyran-2(6H)-one and it is an unsaturated heterocyclic lactone with molecular weighting 154 , stable in acidic medium but unstable in alkaline medium. Patulin is a colorless compound, with a melting point of $110^{\circ} \mathrm{C}$. Maximum absorbance in $\mathrm{UV}$ is at $276 \mathrm{~nm}[6,7]$.

Patulin is very soluble in water and inmost organic solvents. It is stable in diluted acids and resistant to temperatures up to $125{ }^{\circ} \mathrm{C}$, in the $\mathrm{pH}$ range of $3.5-5.5$ [8].

The presence of patulin in 144 apple-based-foods in Portugal was studied by Barreira [9]. Patulin was detected in 32 samples, its concentration being in the range of $1.2-42 \mu \mathrm{g} / \mathrm{kg}$. In the mentioned study patulin was not detected in infant drinks, but was quantified in five homogenised apple puree intended tofeed infants and young children. At the same time, 67\% positive samples were detected in cloudy juices and $13 \%$ in clear juices.

Presence of patulin in organic and conventional apple-based food marketed in Catalonia, as well as the exposure of infants and young children, were studied by Piqué [10]. The estimated daily intake of patulin for infants and young children (0-3 years), children (4-18 years) and adults (19-66 years), was under the provisional maximum tolerable daily intake (PMTDI) of $0.4 \mu \mathrm{g} / \mathrm{kg}$ by weight.

This paper describes the development and validation of a method for determination of patulin by HPLC-DAD from apple puree and apple and fruit puree, purchased from supermarkets and pharmacies in Bucharest. At the same time, apple puree samples are prepared within the Pilot Experiments Plant for Vegetables and Fruits Processing from INCDBA-IBA Bucharest, using two apple varieties intended for processing, from conventional and uncertified organic cultures.

\section{Materials and Methods}

\subsection{Food Matrices and Samples}

Samples used in this study were purchased from the market and pharmacies shelves in Bucharest as well as apple puree samples which have been prepared within the Pilot Experiments Plant for Vegetables and Fruits Processing from INCDBA-IBA Bucharest. In these experiments, two apple varieties intended for processing (Jonathan, Florina) and obtained by conventional and uncertified organic cultures have been used. The apples have been purchased from the market of local farmers. Technological flowchart of apple puree processing has the following technological operations: washing, cutting, blanching, pulping, dosing (in glass recipients capacity $220 \mathrm{~mL}$ ), closing, pasteurization $\left(10\right.$ minutesat $\left.100^{\circ} \mathrm{C}\right)$, cooling (at $40{ }^{\circ} \mathrm{C}$ ) and storage.

\subsection{Methods}

Samples of apple puree and apple and fruit puree were chemically-physically analysed using the following methods:

SR ISO 2173: 2008. Fruit and vegetable products. Determination of soluble dry matter by refractometry;

SR ISO 1842:2008. Fruit and vegetable products. Determination of $\mathrm{pH}$.

\subsection{Determination of Patulin}

2.3.1 Reagents and Materials

HPLC grade glacial acetic acid, HPLC grade ethyl 
acetate and HPLC grade methanol have been purchased from SIGMA-ALDRICH. Optigrade acetonitrile have been purchased from LGC Standards and ultrapure water was obtained in house using ELGA water ultrapurification system. For calibration curves, patulin standard $(5 \mathrm{mg}$, purity $=99.5 \%)$ was obtained from Sigma-Aldrich (St Louis, MO. USA).

AFFINIMIP ${ }^{\circledR}$ SPE Patulin cartridges $(6 \mathrm{~mL}-200$ $\mathrm{mg}$ ) and pectinase enzyme have been obtained from Affinisep-Polyintell (Val-de-Reuil, France).

\subsubsection{Sample Preparation}

The steps of the method of determination of patulin in apple puree are shown as below, in cluding sample preparation, weighting, enzyme treatment, centrifugation, extraction and clean-up on AFFINIMIP ${ }$ SPE Patulin cartridges, extract evaporation, residue redissolving, and HPLC-DAD analysis (Fig. 1).

Sample preparation is based on Application note-AFFINIMIP ${ }^{\circledR}$ SPE Patulin $6 \mathrm{mg} / 200 \mathrm{mg}$-apple puree [11]. In a $50 \mathrm{~mL}$ centrifuge vial, $10 \mathrm{~g}$ of apple puree sample, $150 \mu \mathrm{L}$ of pectinase enzyme solution and $10 \mathrm{~mL}$ ultrapure water were mixed. Sample is maintained in a water bath at $40{ }^{\circ} \mathrm{C}$ for 2 hours, and thencentrifuged at $6,000 \mathrm{rpm}$, at $5{ }^{\circ} \mathrm{C}$ for $25 \mathrm{~min}$. The supernatant $(5 \mathrm{~mL})$ is purified on AFFINIMIP ${ }^{\circledR} \mathrm{SPE}$ Patulin cartridge, which has been pre-conditioned with $2 \mathrm{~mL}$ acetonitrile and $1 \mathrm{~mL}$ of ultrapure water. In order to remove interferences, it need to be passed through the cartridge of $4 \mathrm{~mL}$ water $-0.1 \%$ acetic acid, $4 \mathrm{~mL}$ of ultrapure water, then apply vacuum about 10 s. Further, $500 \mu \mathrm{L}$ ethyl ether are passedthroughthe

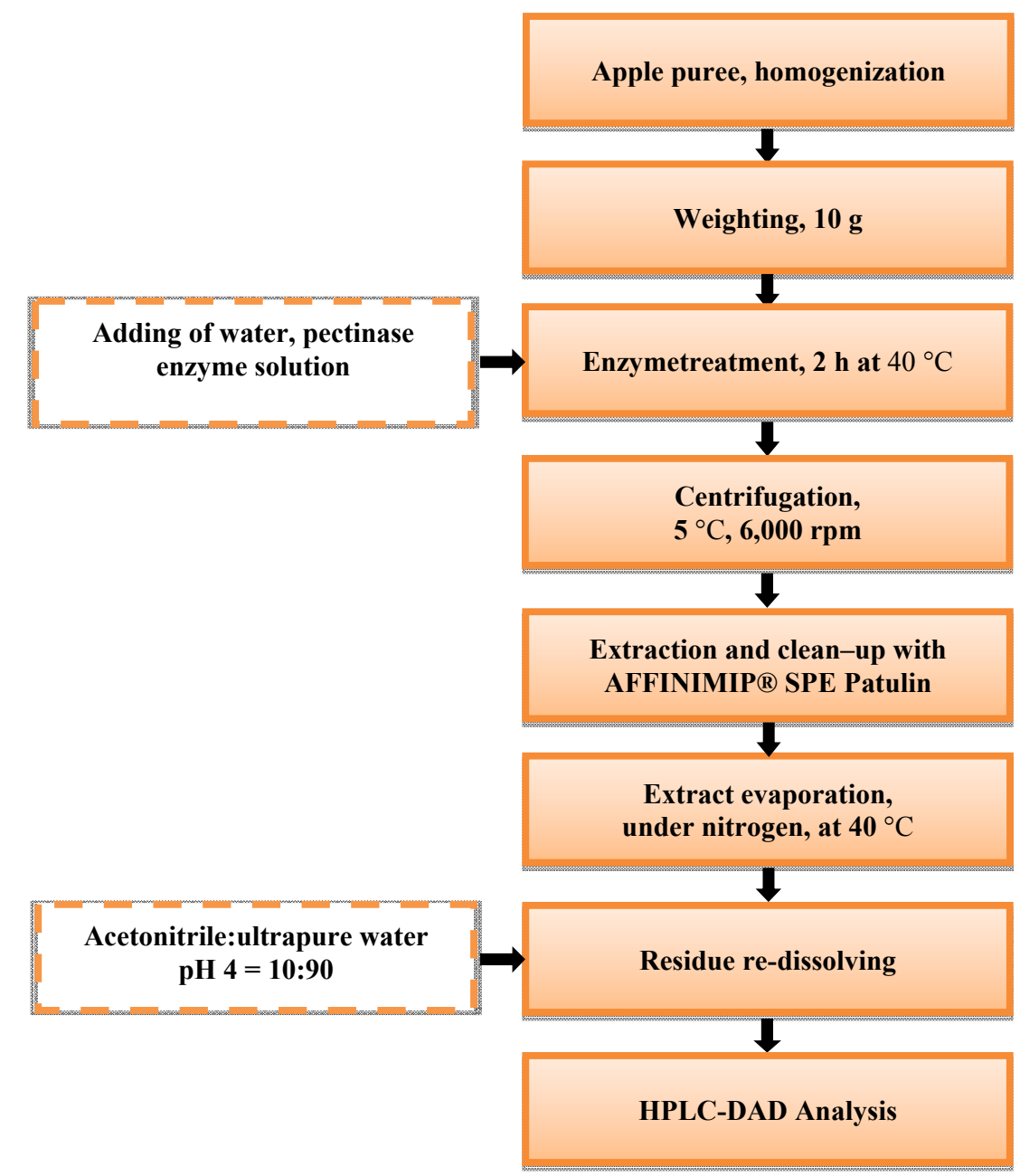

Fig. 1 Flowchart with steps of the method of determination of patulin in apple puree by HPLC-DAD. 
cartridge and finally patulin was eluted with $2 \mathrm{~mL}$ acetonitrile containing $0.1 \%$ acetic acid. The elution fraction is evaporated near dryness under a nitrogen atmosphere at $40{ }^{\circ} \mathrm{C}$, and then re-dissolved in acetonitrile:ultrapure water $(\mathrm{pH}=4)=10: 90 \mathrm{v} / \mathrm{v}$.

2.3.3 Parameters and Conditions of HPLC-DAD Method for Determination of Patulin in Apple Puree

A Surveyor Plus (Thermo Finnigan) high performance liquid chromatograph was used (vacuum degasser, quaternary pump, autosampler with PELTIER sample temperature control, column compartment with PELTIER temperature control, diode array detector, Chrom Quest 4.2 software for data acquisition and data processing). The separation was performed at $25{ }^{\circ} \mathrm{C}$, on a C18 (Hypersil GOLD $150 \mathrm{~mm} \times 4 \mathrm{~mm}, 5$ $\mu \mathrm{m})$ with a Hypersil Gold guard column $(10 \mathrm{~mm} \times 4$ $\mathrm{mm}, 5 \mu \mathrm{m})$. The composition of mobile phase was water acetonitrile $(95: 15, \mathrm{v} / \mathrm{v})$. The injection volume was $25 \mu \mathrm{L}$; the flow rate of the mobile phase was 1.0 $\mathrm{mL} / \mathrm{min}$. And the detection wavelength was $276 \mathrm{~nm}$. Peak identification was based on retention time, spectral information and spiking technique. Peak quantification was based on the external standard method, using calibration curve.

\section{Results and Discussions}

The developed method was validated according to the provisions of the Regulation (EC) No 401/2006 [12].

\subsection{Linearity}

The linearity of the method for determination of patulin in apple puree was evaluated by the method of least squares (linear regression method), for calibration with external standard. For calibration curve, patulin standard (5 $\mathrm{mg}$ ) was dissolved in ethyl acetate and then this solution was diluted with ethanol. Patulin concentration in this solution (10 $\mu \mathrm{g} / \mathrm{mL}$ ) was tested on the basis of maximum absorbance spectrum between $250 \mathrm{~nm}-350 \mathrm{~nm}$ (Fig. 2), based on Eq. (1):

$$
\rho_{\text {pat }}=\mathrm{A}_{\max } x \frac{\mathrm{M} x 100}{\varepsilon \times \delta}
$$

where:

$\rho_{p a t}-$ concentration of patulin solution, expressed as $\mu \mathrm{g} / \mathrm{mL}$;

$A_{\max }$-corresponding absorbance of maximum absorption curve $(276 \mathrm{~nm})$;

$M$-patulin molecular weight $(M=154.12 \mathrm{~g} / \mathrm{mol})$;

$\varepsilon$-relative molar absorption coefficient of patulin in ethanol (in this case $1,460 \mathrm{~m}^{2} / \mathrm{mol}$, according to AOAC Official Methods, 1995, Natural Toxins, Patulin, 49.6.01. C (d))

$\delta$ - the optical path length of quartz cuvette in $\mathrm{cm}$.

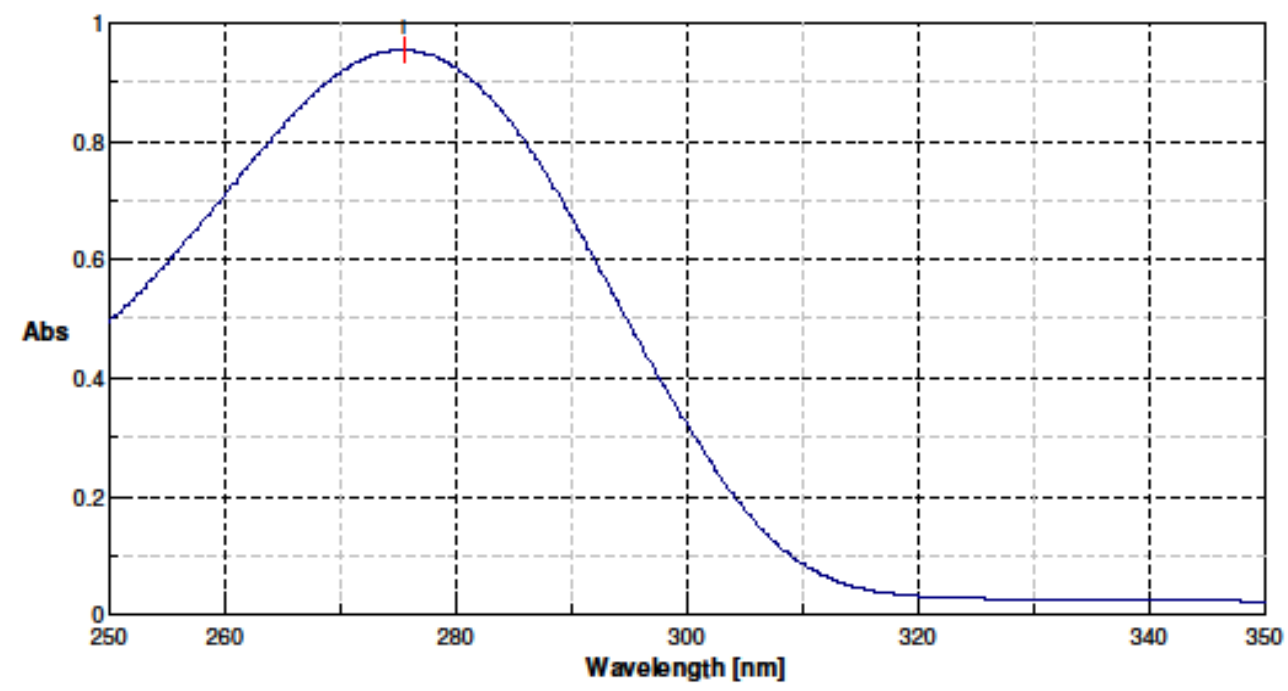

Fig. 2 Spectrum of patulin alcoholic solution. 


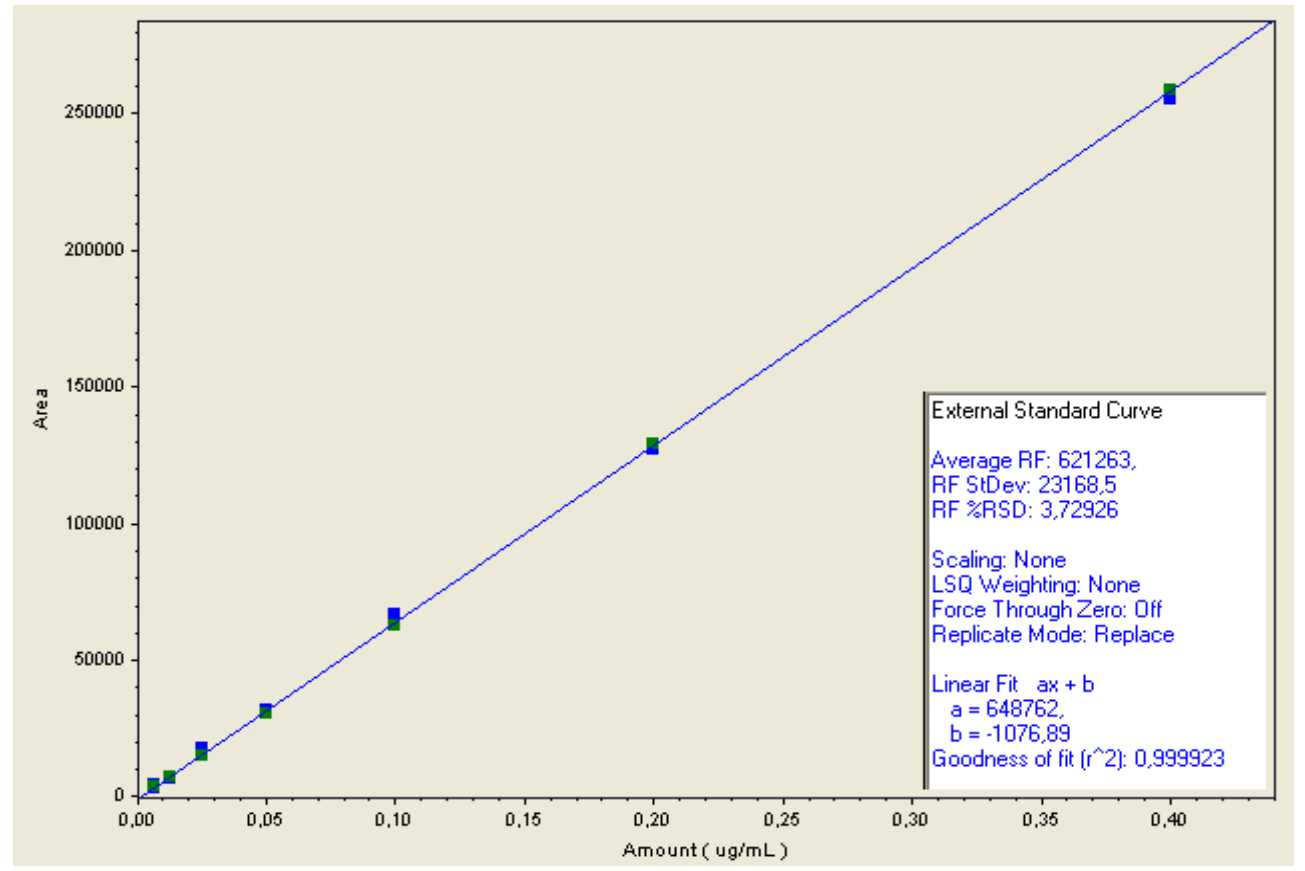

Fig. 3 Patulin calibration curve.

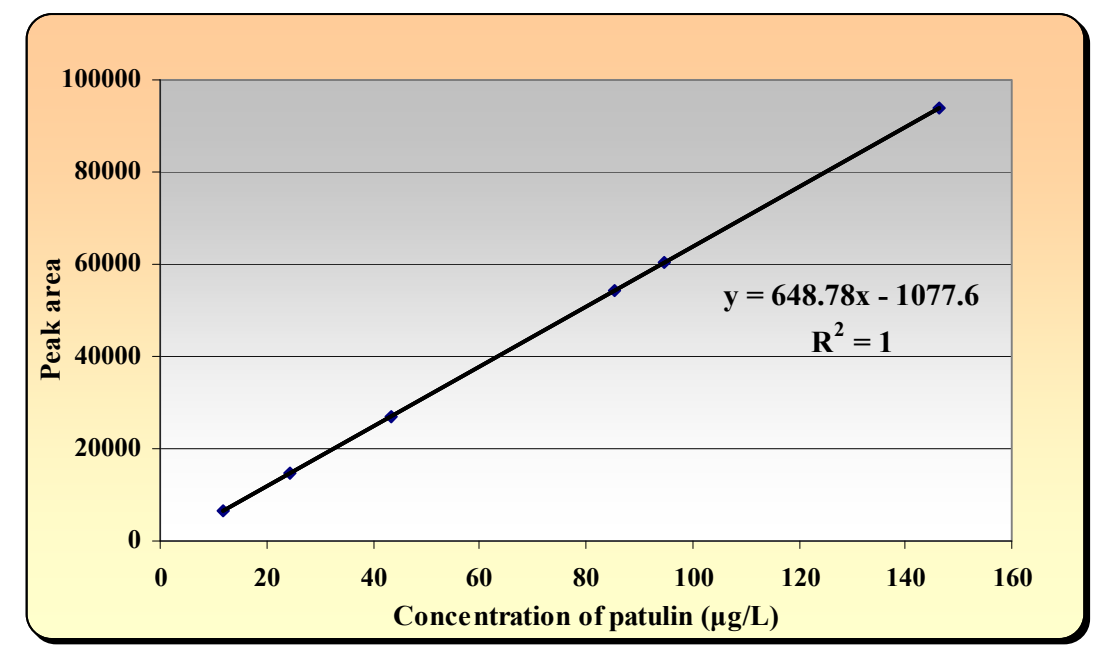

Fig. 4 Linearity domain of method for patulin determination in apple puree, by high performance liquid chromatography.

In the case of the achieved solution $\mathrm{A}_{\max }=0.9479$, the concentration of solution was $\rho_{\text {pat }}=10.00 \mu \mathrm{g} / \mathrm{mL}$.

Seven patulin standard levels (with three replicate injections from each level), in concentration range from $6.25 \mu \mathrm{g} / \mathrm{L}$ to $400 \mu \mathrm{g} / \mathrm{L}$, have been used for the calibration curve (Fig.3) [13].

The following linear regression values were obtained from the linear regression equation: $\mathrm{y}=$ $648762 \mathrm{x}$ - 1076.89; regression coefficient $\mathrm{R}^{2}=$ 0.999923 , slope $b=-1076.89$, intercept $\mathrm{a}=648762$.

Linearity range of the method was determined by analysis of some blank samples of apple puree, which have been spiked with the following patulin concentrations: $5 \mu \mathrm{g} / \mathrm{kg}, 10 \mu \mathrm{g} / \mathrm{kg}, 20 \mu \mathrm{g} / \mathrm{kg}, 40 \mu \mathrm{g} / \mathrm{kg}$, $50 \mu \mathrm{g} / \mathrm{kg}$ and $80 \mu \mathrm{g} / \mathrm{kg}$. By plotting patulin concentration in the injected test sample versus the peak area, the following linear regression equationwas obtained $\mathrm{y}=648.78 \mathrm{x}-1077.6$, with regression coefficient $R^{2}=1$ (Fig. 4).

The linearity domain of method for patulin determination from apple puree, by high performance chromatography is $11.69 \mu \mathrm{g} / \mathrm{L}-146.42 \mu \mathrm{g} / \mathrm{L}$, which is 
equivalent to the range of $5 \mu \mathrm{g} / \mathrm{kg}-80 \mu \mathrm{g} / \mathrm{kg}$ of patulin in apple puree.

\subsection{Recovery}

Apple puree samples in which patulin which was not detected (blank samples), were spiked with patulin (using patulin standard solution for calibration, with patulin concentration of $1 \mu \mathrm{g} / \mathrm{mL}$ ) in the following concentrations: $5 \mu \mathrm{g} / \mathrm{kg}, 10 \mu \mathrm{g} / \mathrm{kg}, 20 \mu \mathrm{g} / \mathrm{kg}, 40 \mu \mathrm{g} / \mathrm{kg}$, $50 \mu \mathrm{g} / \mathrm{kg}, 60 \mu \mathrm{g} / \mathrm{kg}$ and $80 \mu \mathrm{g} / \mathrm{kg}$. These samples were analysed to determine patulin concentration (each concentration level was analyzed in 6 parallel prepared samples), and the following mean recovery values were obtained:

- $91.36 \%$, in the case of patulin concentrations, $<$ $20 \mu \mathrm{g} / \mathrm{kg}$;

- $81.60 \%$, in the range of patulin concentrations, $20-50 \mu \mathrm{g} / \mathrm{kg}$;

- $75.17 \%$, in the case of patulin concentrations, $>$ $50 \mu \mathrm{g} / \mathrm{kg}$.

In the concentration range of $5 \mu \mathrm{g} / \mathrm{kg}$ and $80 \mu \mathrm{g} / \mathrm{kg}$, mean recovery was $81.47 \%$. According to the obtained results, mean recovery, for the ranges of concentrations mentioned above, was under the provisions of the Regulation (EC) No. 401/2006 [12].

\subsection{Precision, Repeatability and i-Intra-laboratory} Reproducibility

To evaluate the instrument precision, 6 consecutive injections of apple puree samples (blank) spiked with patulin, at two concentration levels of $5 \mu \mathrm{g} / \mathrm{kg}$ and 10 $\mu \mathrm{g} / \mathrm{kg}$, have been used. The following parameters have been calculated: patulinmean concentration, mean recovery, standard deviation in repeatability conditions $\mathrm{SD}(\mathrm{r})$ and relative standard deviation in repeatability conditions $\operatorname{RSD}(\mathrm{r})$ (Table 1$)$.

In order to verify method precision, 6 parallel samples of apple puree (blank) spiked with patulin at two concentration levels of $10 \mu \mathrm{g} / \mathrm{kg}$ and $40 \mu \mathrm{g} / \mathrm{kg}$ were analysed by the same analyst, in the same laboratory and using the same instrument. The following parameters have been calculated: patulinmean concentration, standard deviation in repeatability conditions $\mathrm{SD}(\mathrm{r})$, relative standard deviation in repeatability conditions $\operatorname{RSD}(\mathrm{r})$, repeatability limit and expanded uncertainty (Table 2).

For evaluating the intra-laboratory reproducibility, 6 sampleshave been analyzed by two analysts (analyst A -3 samples, analyst B-3 samples) of apple puree (blank) spiked with patulin, at one concentration level of $20 \mu \mathrm{g} / \mathrm{kg}$ performed in the same laboratory and using the same instrument. The following parameters have been calculated: patulin mean concentration, standard deviation in reproducibility conditions $\mathrm{SD}(\mathrm{R})$, relative standard deviation in reproducibility conditions $\mathrm{RSD}(\mathrm{R})$, reproducibility limit and expanded uncertainty (Table 3 ).

According to the obtained results, relative standard deviation achieved under repeatability conditions $\mathrm{RSD}(\mathrm{r})$ and relative standard deviation achieved under

Table 1 Statistical parameters for repeatability (instrument precision), in the case of method for determination of patulin in apple puree.

\begin{tabular}{llllll}
\hline Sample name & Spiking level $(\mu \mathrm{g} / \mathrm{kg})$ & $\begin{array}{l}\text { Mean value } \\
\mathrm{C}_{\text {Patulin }}(\mu \mathrm{g} / \mathrm{kg})\end{array}$ & $\begin{array}{l}\text { Mean value } \\
\text { recovery }(\%)\end{array}$ & $\begin{array}{l}\mathrm{SD}(\mathrm{r}) \\
(\mu \mathrm{g} / \mathrm{kg})\end{array}$ & $\begin{array}{l}\text { RSD(r) } \\
(\%)\end{array}$ \\
\hline Apple puree & $5(\mathrm{n}=6)$ & 4.67 & 93.14 & 0.12 & 2.66 \\
Apple puree & $10(\mathrm{n}=6)$ & 9.03 & 90.27 & 0.08 & 0.86 \\
\hline
\end{tabular}

Table 2 Statistical parameters for repeatability (method precision), in the case of method for determination of patulin in apple puree.

\begin{tabular}{llllllll}
\hline Sample name & $\begin{array}{l}\text { Spiking level } \\
(\mu \mathrm{g} / \mathrm{kg})\end{array}$ & $\begin{array}{l}\text { Mean value } \\
\mathrm{C}_{\text {Patulin }}(\mu \mathrm{g} / \mathrm{kg})\end{array}$ & $\begin{array}{l}\mathrm{SD}(\mathrm{r}) \\
(\mu \mathrm{g} / \mathrm{kg})\end{array}$ & $\begin{array}{l}\mathrm{RSD}(\mathrm{r}) \\
(\%)\end{array}$ & $\begin{array}{l}\text { Repeatability } \\
\text { limit, } \mathrm{r}(\mu \mathrm{g} / \mathrm{kg})\end{array}$ & $\begin{array}{l}\text { Expanded } \\
\text { uncertainty } \\
(\mu \mathrm{g} / \mathrm{kg})\end{array}$ & $\begin{array}{l}\text { Confidence } \\
\text { interval }(\mu \mathrm{g} / \mathrm{kg})\end{array}$ \\
\hline Apple puree & $10(\mathrm{n}=6)$ & 10.44 & 0.67 & 6.40 & 1.87 & 1.36 & $10.44 \pm 1.36$ \\
Apple puree & $40(\mathrm{n}=6)$ & 40.69 & 0.97 & 2.39 & 2.73 & 2.55 & $40.69 \pm 2.55$ \\
\hline
\end{tabular}


Table 3 Statistical parameters for intra-laboratory reproducibility, in the case of method for determination of patulin in apple puree.

\begin{tabular}{|c|c|c|c|c|c|c|c|}
\hline Sample name & $\begin{array}{l}\text { Spiking level } \\
(\mu \mathrm{g} / \mathrm{kg})\end{array}$ & $\begin{array}{l}\text { Mean value } \\
C_{\text {Patulin }} \\
(\mu \mathrm{g} / \mathrm{kg})\end{array}$ & $\begin{array}{l}\mathrm{SD}(\mathrm{R}) \\
(\mu \mathrm{g} / \mathrm{kg})\end{array}$ & $\begin{array}{l}\mathrm{RSD}(\mathrm{R}) \\
(\%)\end{array}$ & $\begin{array}{l}\text { Reproducibility } \\
\text { limit, } \mathrm{R}(\mu \mathrm{g} / \mathrm{kg})\end{array}$ & $\begin{array}{l}\text { Expanded } \\
\text { uncertainty } \\
(\mu \mathrm{g} / \mathrm{kg})\end{array}$ & $\begin{array}{l}\text { Confidence } \\
\text { interval }(\mu \mathrm{g} / \mathrm{kg})\end{array}$ \\
\hline Apple puree & $20(n=6)$ & 20.52 & 1.11 & 5.41 & 3.11 & 1.78 & $20.52 \pm 1.78$ \\
\hline
\end{tabular}

reproducibility conditions $\mathrm{RSD}(\mathrm{R})$, in thecase of method for determination of patulin in apple puree by high performance liquid chromatography, were within the provisions of the Regulation (EC) No. 401/2006 (EC regulation 2006a).

\subsection{Limit of Detection (LOD) and Limit of Quantification (LOQ)}

Limit of detection (LOD) represents concentration at which signal/noise ratio is higher than $3(\mathrm{~S} / \mathrm{N}>3)$. Limit of quantification $(L O Q)$ is defined as being the lowest concentration of analyte which can be determined with an acceptable precision, in the conditions of a method of analysis, at a signal/noise ratio higher than $10(\mathrm{~S} / \mathrm{N}>10)$. The obtained results were as follows: $\mathrm{LOD}=3.11 \mu \mathrm{g} / \mathrm{L}(1.36 \mu \mathrm{g} / \mathrm{kg})$ and $\mathrm{LOQ}=10.40 \mu \mathrm{g} / \mathrm{L}(4.55 \mu \mathrm{g} / \mathrm{kg})$.

Of the 17 commercial samples, none of them excedeed the maximum level of the CE Regulation (EC 1881/2006 (2006a) for patulin content (25 $\mu \mathrm{g} / \mathrm{kg}$ ), when 11 samples patulin was not detected. The mean concentration of patulin, taking into consideration only the positive samples (samples with patulin concentration > LOQ), was $7.78 \mu \mathrm{g} / \mathrm{kg}$ and the incidence of positive samples was $35.29 \%$ (Table 4). Maximum patulin concentration of the analysed samples puree was $10.55 \mu \mathrm{g} / \mathrm{kg}$ (Fig. 5). The analysed puree samples contain apple puree $(90 \%)$ and other ingredients (glucose-fructose syrup, sugar and citric acid), their dry matter being in the range 17.6 to $17.8^{\circ}$ Brix, and $\mathrm{pH}$ in the range 3.45 to 3.56 .

Samples of apple puree prepared from two apple varieties intended for processing (Jonathan, Florina) fall under the maximum level of the EC Regulation $1881 / 2006$ [13] for patulin content (25 $\mu \mathrm{g} / \mathrm{kg})$. Samples of apple puree prepared from apples obtained from conventional cultures have a lower patulin content in comparison with those obtained from uncertified organic cultures (Table 4).

In the case of samples of apple puree prepared from apple, Jonathan variety, the mean patulin concentration (taking into consideration only the positive samples)

Table 4 Concentration of patulin in apple puree and apple and fruit puree.

\begin{tabular}{|c|c|c|c|c|c|c|c|}
\hline \multirow[b]{2}{*}{ Production method } & \multirow{2}{*}{$\begin{array}{l}\text { Positive } / \\
\text { total }\end{array}$} & \multirow[b]{2}{*}{$\%$ Positives } & \multicolumn{3}{|c|}{ Number of samples } & \multirow{2}{*}{$\begin{array}{l}\text { Max. } \\
(\mu \mathrm{g} / \mathrm{kg})\end{array}$} & \multirow{2}{*}{$\begin{array}{l}\text { Mean } \pm \text { SD positive } \\
\text { samples }(\mu \mathrm{g} / \mathrm{kg})\end{array}$} \\
\hline & & & $<\mathrm{LOD}$ & $<$ LOQ & $\begin{array}{l}4.62-10.55 \\
(\mu \mathrm{g} / \mathrm{kg})\end{array}$ & & \\
\hline \multicolumn{8}{|l|}{ Conventional } \\
\hline Commercial samples & $6 / 17$ & 35.29 & 11 & 0 & 6 & 10.55 & $7.78 \pm 1.58$ \\
\hline Apple puree from Jonathan & $5 / 10$ & 50 & 4 & 1 & 5 & 6.13 & $5.42 \pm 0.54$ \\
\hline Apple puree from Florina & $5 / 12$ & 41.66 & 5 & 2 & 5 & 5.19 & $4.93 \pm 0.22$ \\
\hline \multicolumn{8}{|l|}{ Uncertified organic } \\
\hline Apple puree from Jonathan & $5 / 10$ & 50 & 3 & 2 & 5 & 7.37 & $6.20 \pm 0.95$ \\
\hline Apple puree from Florina & $5 / 9$ & 55.55 & 4 & 0 & 5 & 6.44 & $5.50 \pm 0.60$ \\
\hline \multicolumn{8}{|l|}{ Organic } \\
\hline $\begin{array}{l}\text { Blueberries and apple puree } \\
\text { (forinfants and young children) }\end{array}$ & $0 / 5$ & 0 & 5 & 0 & 0 & - & - \\
\hline $\begin{array}{l}\text { Banana and apple puree } \\
\text { (forinfants and young children) }\end{array}$ & $0 / 5$ & 0 & 5 & 0 & 0 & - & - \\
\hline
\end{tabular}




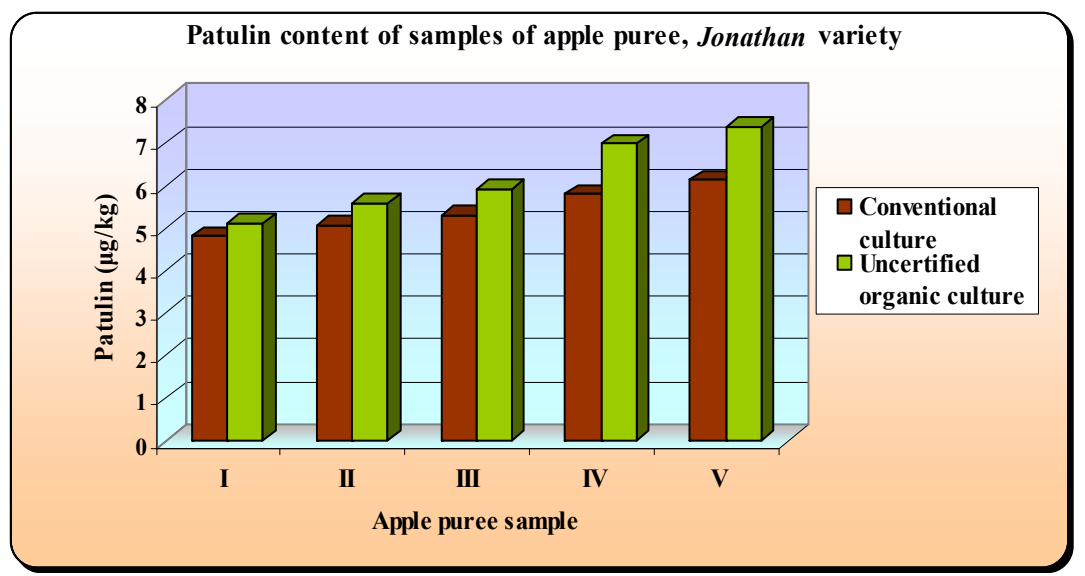

Fig. 5 Patulin content of samples of apple puree, Jonathan variet.

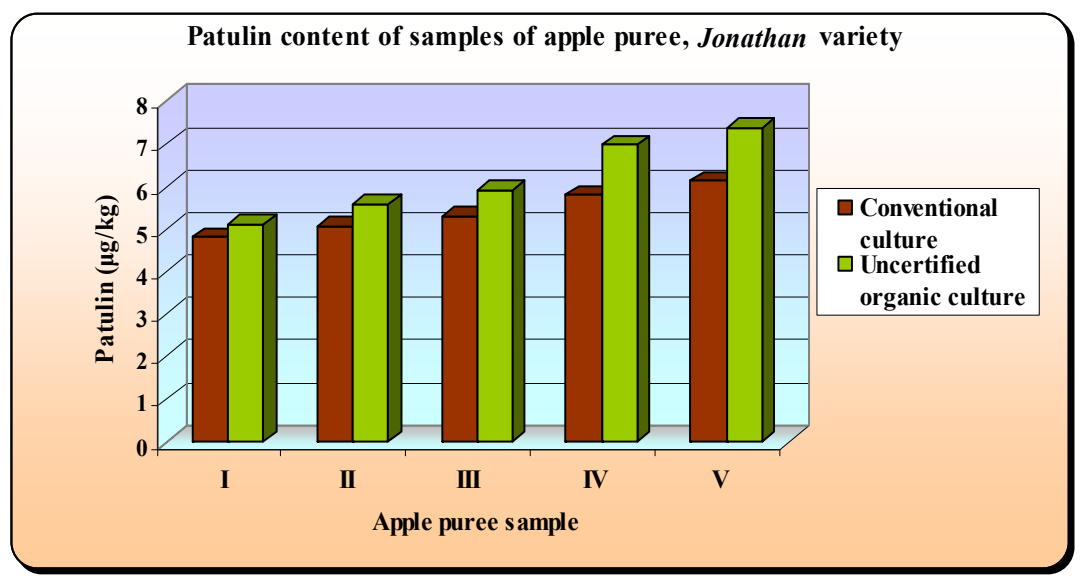

Fig. 6 Patulin content of samples of apple puree, Jonathan variety.

was $5.42 \mu \mathrm{g} / \mathrm{kg}$, and the apple obtained from conventional culture, $6.20 \mu \mathrm{g} / \mathrm{kg}$, in the case of those from uncertified organic culture.

In the case of 7 apple puree samples prepared from apple, Jonathan variety (4 samples of apple puree from apple obtained from conventional culture, 3 samples of apple puree from uncertified organic culture, respectively), patulin was not detected (Table 4). Concentration of patulin ranged from 4.81 to 7.37 $\mu \mathrm{g} / \mathrm{kg}$ (Fig. 6), $\mathrm{pH}$ in the range of 3.37 to 3.51 , and soluble dry matter in the range of 9.5 to $10.2^{\circ}$ Brix.

Based on the results obtianed from the analysis of patulin concentration of puree samples, prepared from apple, Jonathan variety, there is a linear correlation, described by the equation $y=-13.595 x+52.509$ (in case of apple from conventional culture) and $\mathrm{y}=$ $-19.064 x+71.511$ (in case of apple from uncertified organic culture) respectively, while patulin concentration being inversely proportional with the pH of apple puree (Figs. 7 and 8).

In the case of apple puree samples prepared from apple, Florina variety, patulin concentration ranged from $4.62 \mu \mathrm{g} / \mathrm{kg}$ to $6.44 \mu \mathrm{g} / \mathrm{kg}$, being slightly lower than that recorded by samples of apple puree prepared from Jonathan variety (Fig. 9). From the samples studied, there were $41.66 \%$ positive samples in the case of puree prepared from conventional apple (maximum concentration being of $5.19 \mu \mathrm{g} / \mathrm{kg}$ ), respectively $55.55 \%$ positive samples, in case of puree prepared from uncertified organic apple (maximum concentration being of $6.44 \mu \mathrm{g} / \mathrm{kg}$ ). $\mathrm{pH}$ is ranged from 3.7 to 3.83 .

Also, in case of Florina variety samples, a linear correlation has been observed between their patulin concentration and $\mathrm{pH}$ values, described by equations from Figs. 10 and 11. 
High Performance Liquid Chromatography

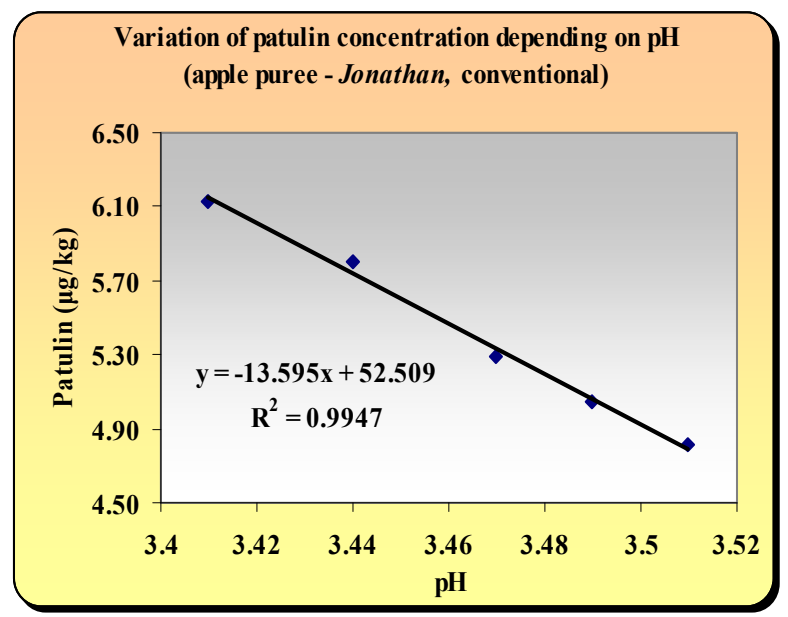

Fig. 7 Variation of patulin concentration depending on pH (apple puree—Jonathan, conventional).

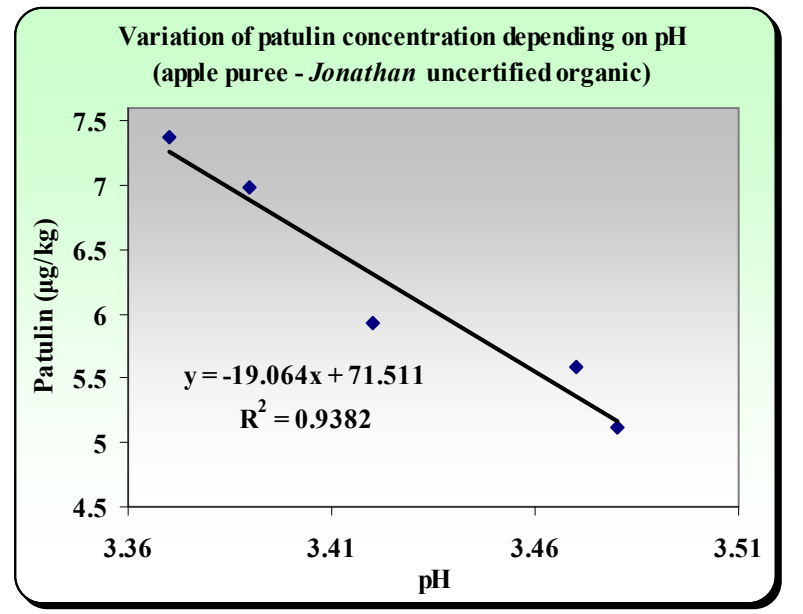

Fig. 8 Variation of patulin concentration depending on pH (apple puree—Jonathan, uncertified organic).

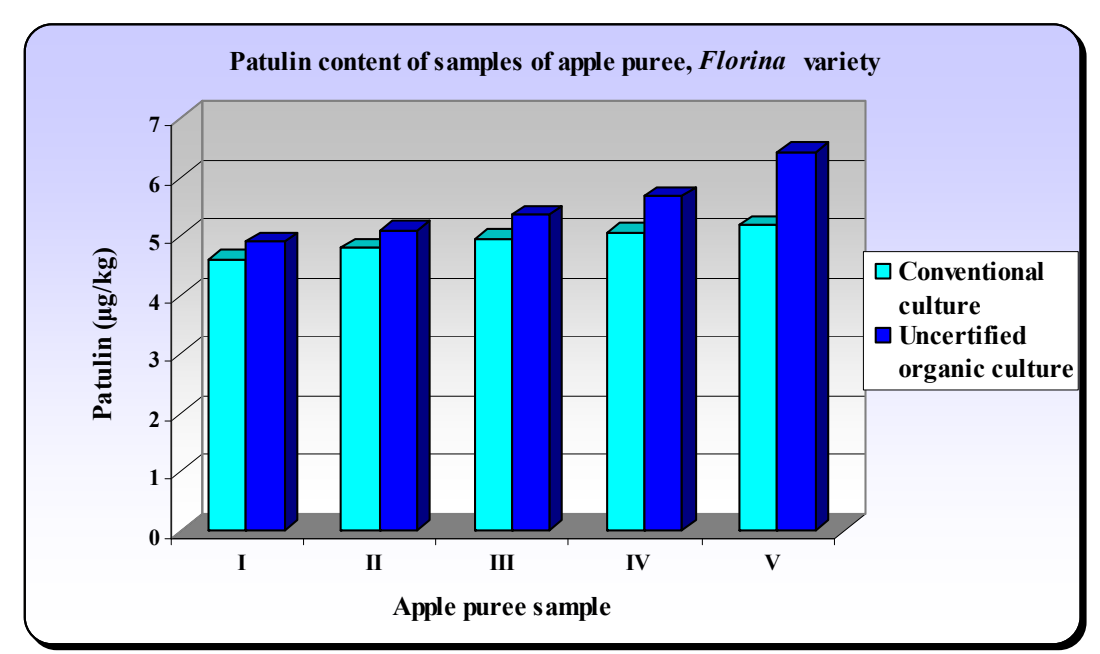

Fig. 9 Patulin content of samples of apple puree, Florina variety.

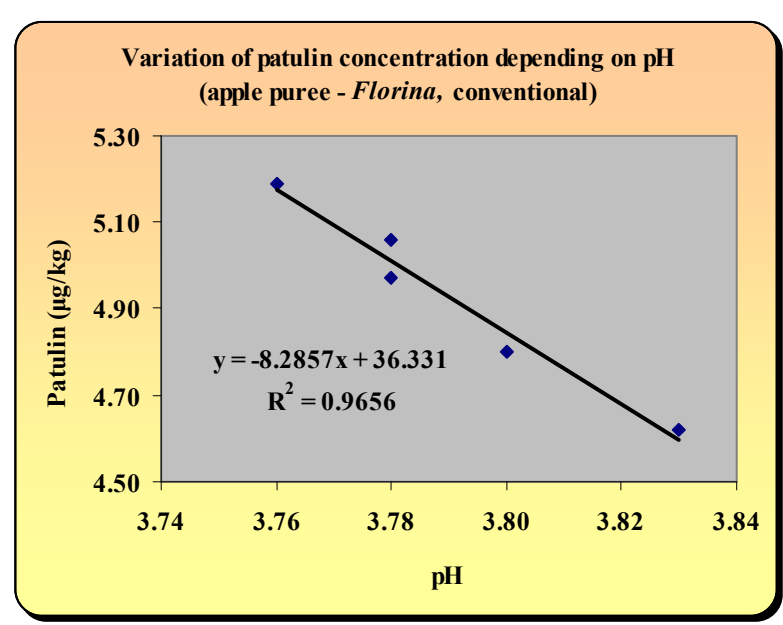

Fig. 10 Variation of patulin concentration depending on pH (apple puree—Florina, conventional).

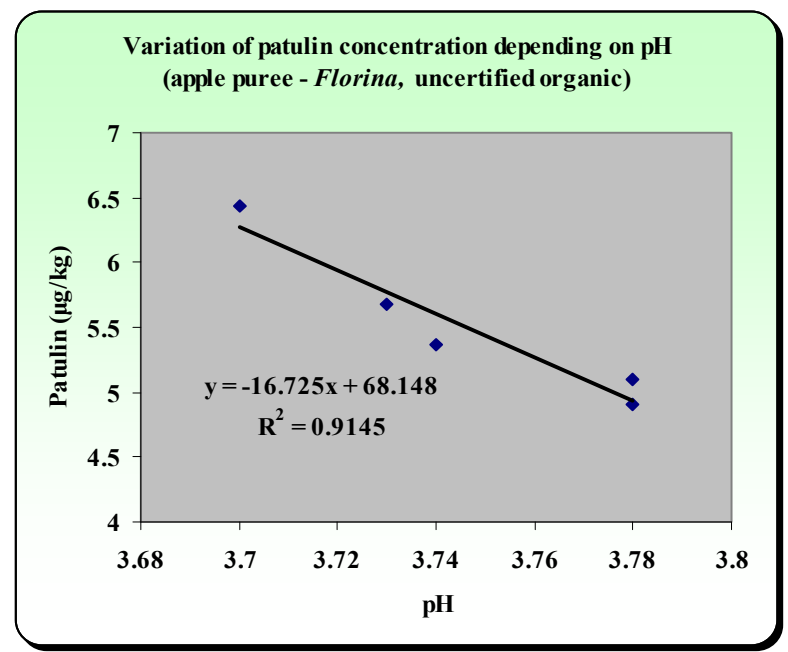

Fig.11 Variation of patulin concentration depending on pH (apple puree—Florina). 
Patulin was not detected from the apple and fruit puree samples intended for consumption by infants and young children (Blueberries and apple puree, Banana and apple puree) which were analysed in this study.

\section{Conclusions}

Within Human Nutrition Laboratory from the National R \& D Institute for Food Bioresources-IBA Bucharest, an analytical method was developed and validate dan for determination of patulin in apple puree and apple and fruit puree by high performance liquid chromatography (HPLC-DAD). The proposed method has a good sensitivity (LOD $=$ $1.36 \mu \mathrm{g} / \mathrm{kg}$ and $\mathrm{LOQ}=4.55 \mu \mathrm{g} / \mathrm{kg}$ ) and allows determination with a good precision of patulin concentration in samples of apple puree, apple and fruit puree respectively.

A number of 26 samples of apple puree (commercial samples, samples prepared within IBA Bucharest using apple intended for processing, from two varieties, both from the conventional culture and uncertified organic culture) were analysed using the proposed method withpatulin concentration ranged from $4.62 \mu \mathrm{g} / \mathrm{kg}$ to $10.55 \mu \mathrm{g} / \mathrm{kg}$ (appreciably lower than the maximum level allowed by the present legislation-25 $\mu \mathrm{g} / \mathrm{kg}$ ), and in case of those 27 samples of apple puree, patulin was not detected. Also, in case of 5 samples of apple puree, patulin concentration was lower than the limit of quantification of the method $(4.55 \mu \mathrm{g} / \mathrm{kg})$.

Apple puree samples prepared from apple intended for processing, but from uncertified organic cultures, showed a patulin concentration slightly higher than of those from conventional ones, which wereunder the maximum level allowed by the legislation into force.

\section{Compliance with Ethical Standards}

Funding: This study was supported by the Ministry of National Education-State Authority for Scientific
Research, Technological Development and Innovation, by Nucleu Programme PN 12 48, contract 48 N/2012.

\section{Conflict of interest}

The authors declare no conflict of interest.

\section{References}

[1] Puel, O., Galtier, P., and Oswald, I. P. 2010. "Biosynthesis and Toxicological Effects of Patulin." Toxins 2: 613-631.

[2] Hopkins, J. 1993. "The Toxicological Hazards of Patulin." Food and Chemical Toxicology 31: 455-456.

[3] Moake, M., Padilla-Zakour. O., and Worobo, R. 2005. "Comprehensive Review of Patulin Control Methods in Foods." Compr. Rev. Food Sci. Food Safety 4: 8-21.

[4] World Health Organization. 1995. Evaluation of Certain Food Additives and Contaminants. 44th report of the Joint Food and Agriculture Organization/World Health Organization Expert Committee on Food Additives.

[5] Codex Alimentarius Commission. 2003. "Code of Practice for the Prevention and Reduction of Paulin Contamination in Apple Juice and Apple Juice Ingredients in Other Beverages." $C A / R C P$ 50-2003.

[6] Nielsen K. F., and Smedsgaard, J. 2003. "Fungal Metabolite Screening: Database of 474 Mycotoxins and Fungal Metabolites for Dereplication by Standardised Liquid Chromatography-UV-mass Spectrometry Methodology." Journal of Chromatography A 1002: 111-136.

[7] Ciegler, A., Detroy, R. W., and Lillehoj, E. B. 1971. "Patulin, PenicillicAcid, and Other Carcinogenic Lactones." Microbial Toxins 409-414.

[8] Collin, S., Bodarte, E., Badot, C., Bouseta, A., and Nizet, S. 2008. "Identification of the Main Degradation Products of Patulin Generated through Heat Detoxication Treatments." Journal of the Institute of Brewing 114: 167-171.

[9] Barreira, M. J., Alvito, P. C., and Almeida, C. M. M. 2010. "Occurrence of Patulin in Apple-based-foods in Portugal." Food Chemistry 121: 653-658.

[10] Piqué, E., Vargas-Murga, L., Gomez-Catalan, J., De Lapuente, J., and Llobet, J. M. 2013.“Occurrence of Patulin in Organic and Conventional Apple-based Food Marketed in Catalonia and Exposure Assessment." Food and Chemical Toxicology 60: 199-204.

[11] AFFINIMIP ${ }^{\circledR}$ SPE Patulin Q3. 2013. Application note DETERMINATION OF PATULIN IN APPLE PUREE.

[12] (a) European Commission. 2006. Commission Regulation (EC) No 401/2006 of 23 February 2006. Laying down the 
High Performance Liquid Chromatography

methods of sampling and analysis for the official control of the levels of mycotoxins in foodstuffs. Off. J. Eur. Commun. L, 2006, 70: 12. (b) European Commission. 2006. Commission Regulation (EC) No. 1881/2006 of 19 December 2006. Setting maximum levels for certain contaminants in foodstuffs. 2006R1881-EN-01.09. 2014-014.001-1, 2006.

[13] Catanna, M., Catana, L., Lilios, G., Negoita, M., Iogra, E., Belc, N., et al. 2011. "Determination of Patulin in Apple Juice." Romanian Journal of Food Science 1: 65-69. 